\title{
Teamwork Soft Skill Development In Facing The Globalization
}

\author{
Ramot Peter, Masda Surti Simatupang
}

\begin{abstract}
The globalization has impacted to creating the multicultural business environments that tend to make some handicaps in establishing an effective team in the working area. Teamwork is one of the crucial soft skills that professionals must have in contributing to the succession of a business in the globalization era. This study aims to explore the evidence of the learning process as a contribution to developing the teamwork soft skill for the students as the agents of change for future. The lecturer must play an important role in facilitating the learning process in order to achieve the target. To collect the data, the researhers execute the research by using classroom observation, distributing the questionnaires to the students and interviewing the students and lecturers. The data will be analyzed by using descriptive qualitative analysis. The results show that the students are enthusiastic in developing their teamwork soft skill through implementing the discussion group and finalizing the project group assignment in order to achieve the high scores of assessments. This implies that the students must possess the teamwork soft skill in order to develop an effective team working in facing the multicultural business environment as impacts of the globalization era.
\end{abstract}

Index Terms: Globalization, multicultural, soft skill, teamwork.

\section{INTRODUCTION}

The impact of globalization has made the diversity of religion, ethnic and nationality gathering in the business environment. Nowadays, it becomes an interesting and hot issue to discuss since nobody can avoid the diversity. In a business interaction, the diversity may not be a barrier but it may drive to a creativity and productivity for business development. Reference [1] suggests to developing the required basic skills in order to face the competition in globalization era. The basic required skills are related to hard skills and soft skills. Hard skills are only related to technical skills in cognitive aspects, but soft skills are related to the character, work ethics, dedication, and commitment that cannot be improved instantly. In fact, it is not easy to maintain a good team working in a business environment that gather people from the diversity of religion, race, ethnic, language and other social backgrounds. In this case, we need a teamwork skill.

This matter becomes a phenomenon in a business in order to get a professional that has a good teamwork soft skill.
The teamwork skill is one of the soft skills that business practitioners or professionals at all level must have. The challenge of diversity in a working environment is multi religions. In many religions, most people believe that work means an action to develop the world sustainably with God All kind of works must be in accordance with God's plans to express the values of truthfulness, goodness, fairness, honesty, and humanity. Teamwork must show those values to harmonize the cooperation between workers or employees in order to build the work in a team effectively and productively.

One important component of society that can be developed professionally is the college students. The students are considered to give the high potential impacts for future era as future leaders or agent of change. Reference [2] page 4 states that the college students play a vital role in all areas because of four reasons, they are: 1) as future intellectual; 2) not contaminated with the religion pressure; 3) high idealism to a real action; 4) as future nation leaders. It means that the religion diversity in a classroom learning process can be used as a potential modal for developing the future nation leaders. This process cannot be separated from the role of lecturers in teaching and learning activity. As an educator, the lecturer must be able to utilize all efforts and teaching skills including the material development for developing the students' teamwork skill as it is expected in business interaction.

To get involved in developing the students skills, Bina Nusantara (BINUS) University has developed an integrated system called EES (Employability and Entrepreneurial Skills). The purpose of this concept focus on developing the soft skill in parallel to hard skill (technical skill) as the quality objective and graduate attribute. As the quality objective, one of three graduates must get employed in a global company or becomes a global entrepreneur. And, the graduate attributes that the graduates must have are the technical competence, numerical literacy, ICT skills, languages proficiency, international experience, and six key soft skills. The six soft skills are related to self-management, team work, communication, problem solving and decision making, planning and organizing, initiative and enterprise.

Revised Manuscript Received on April 19, 2019.

Ramot Peter, Character Buiding Development Center, Information Systems Department, School of Information Systems, Bina Nusantara University, Jakarta, Indonesia.

Masda Surti Simatupang, Faculty of Letters, Christian University of Indonesia, Jakarta, Indonesia. 
Those six soft skills are integrated with major of Character Building $(\mathrm{CB})$ development. In relation with this topic, the development, observation, and assessment. Consequently, the CB Religiosity lecturer must play a vital role in developing the teamwork soft skill, motivating the students, facilitating the students. On the other hand, the students must be active to participate in order to achieve the target of competency base curriculum.

At the end of this research, the writers describe the main purposes of this research by focusing on description of the followings: 1) the roles of lecturers; 2) the learning process; 3) the supporting factors; 4) the impacts of the learning process to develop the students' soft skill in teamwork. The results of this research are expected to give some benefits including: 1) to prepare the students for facing the employment competition in the globalization era, 2) to help the lecturers acquiring the teaching skill development and teaching material enrichment.

\section{LITERATURE REVIEW}

In this chapter, the writers explain some important terminology and issues about the topic as follows: 1) the Impacts of Globalization; and, 2) Teamwork as Soft Skill. Those two theoretical frameworks must be useful to open minds about globalization impacts and teamwork understandings.

\section{A. The Impacts of Globalization}

According to Webster Dictionary, globalization is the act or process of globalizing. Today is the era of globalization and no one can get rid of it. Even it has broken the boundary among countries, as if there is no wall between countries. Reference [3] describes that one of the widely accepted consequences of globalization is the development of individual outlooks, behaviors and feelings that transcend local and national boundaries. In this case, the impact of globalization has created the multicultural crowds at any sector with the diversity of religion, ethnic, and nationality gathering in the business environment. Nowadays, it becomes an interesting and hot issue to discuss since nobody can avoid the diversity. In a business interaction, the diversity may not be a barrier but it is as a 'Given' from God that must be used as an instrument for developing the creativity and productivity that relates to business skills. Reference [4] page 29 states that a good established company nowadays must empower the employees having not only hard skills but also soft skills that relate to the character, work ethics, dedication, and commitment that cannot be improved instantly. This matter becomes a phenomenon in a business in order to get a professional that possesses a good teamwork soft skill.

\section{B. Teamwork as Soft Skill}

Reference [5] page 3 defines that teamwork skill is one of the soft skills that business practitioners at all level must have as a 'very-to-extremely important' skill. One challenge of diversity in a working environment is multi religions. In many religions, most people believe that work means an action to develop the world sustainably with God. Some believers also consider that work is as to worship God. writers focus on the investigation of the team work soft skill

Hence all kind of works must be in accordance with God's plans to express the values of truthfulness, goodness, fairness, honesty, and humanity.

There are found some explanations of the teamwork terminology. According to Webster's New World College Dictionary, the term 'teamwork' means joint action by a group of people, in which individual interests are subordinated to group unity and efficiency. The more creative individuals in a team the more positive synergy will be made to get a success. Reference [6] page 43 states that the success of a teamwork deals with the individual character, integrity, and skill. Another, reference [7] page 466 gives his opinion about teamwork that shows the working in team. Working in a team can give more achievement compared to an individual work, especially if the work environment needs many skillful workers or professionals. Furthermore, reference [8] page 21 defines the working team or team work consists of sportive, sensitive, friendly persons that can handle their emotion effectively.

Based on those theoretical opinions, the writers may conclude that the teamwork is a group of collaborative persons that work with accountability, honesty, reliability, responsibility to achieve the same purposes. Consequently, the phenomenon in business organization nowadays in the globalization era urges to have more skillful workers, especially with the soft skill 'teamwork'. In this case, Bina Nusantara University involves in providing the skillful workers by teaching the subject of Character Building (CB) Religioosity with the theme "Religious Meaning of Work". The purpose is for developing the 'teamwork' soft skill as the target of the learning process.

The integration of the teamwork skill development can be implied as an 'acquired skill' that can be developed by relevant training and education in the classroom. Reference [9] states that collaborative and cooperative forms and other forms of active learning are methods being used in the classroom as ways to promote teamwork among students and enhance their learning. It is observed that negative teamwork experiences discourage both students and lecturers from the continued using teams in the classroom. Hence the lecturers as facilitators must involve in motivating their students to get used to working in a team. Besides, the lecturers must coach the students if they face difficulties to do the teamwork assignment, for instance, with the diversity of religions, ethnic groups, nations, and so forth. By this implementation, the students are expected to have the 'teamwork' soft skill that can be applied to their future business as professionals.

The phenomenon has attracted the researchers to investigate the learning process at Bina Nusantara University as the provider of future professionals, leaders or agents of change for the nation. Reference [10] states "It is important that the ASEAN nations can communicate and work together more effectively in the era of ASEAN Community in 2015 and forward". Based on above statement, the researchers assume that the importance of 
'work together' or 'teamwork' skill must play a vital role in facing the new era, i.e. ASEAN Community and globalization. The effect of globalization, that increases the utilization of multicultural teams, leads organizations and universities to become more aware of the importance of diverse teams. Working in teams can help the students to learn and experience how to deal with different people, to develop opinions and ideas, to learn to respect and trust reference [12] page 225 states that teamwork is the effective way to be implemented to encounter the multi religions among students. The lecturers must play the vital roles mainly in developing the students' soft skill, namely 'teamwork' by constructing lesson preparation, facilitating the learning process, coaching the students and assessing their achievements as the results of teamwork

\section{METHODOLOGY/ MATERIALS}

This study investigates the implementation of teamwork building in the learning process for the students at Bina Nusantara University. The researchers use the descriptive qualitative method to describe the data systematically, factually, and accurately against facts and phenomenon [13] page 54. The participants of this research are fifty two students and three lecturers of Bina Nusantara University. classroom, questionnaires to students, and interview with the lecturers. The unstructured observation in classroom is aimed to find the effectiveness of teamwork building in learning process without predetermined variables. The questionnaires, consisting of twenty questions, to the students are classified into four categories: 1) the role of lecturers, 2) the effectiveness of learning process, 3) the supporting factors, and 4) the impacts of learning process to the students' character and achievements. The researchers conduct the unstructured interview with the three lecturers in an informal manner to acquire the implementation of teamwork building in learning process experience.

The collected data are analyzed based on data tabulation, calculation, and classification. The researchers make the description of the research systematically, factually, and accurately to describe the facts, the definition, the function and to figure out the relationship between the phenomenon. This research describes the feedback from the students and the important roles of the lecturers in developing the teamwork soft skill for the students of Bina Nusantara University in Jakarta.

\section{RESULTS AND FINDINGS}

The writers made some efforts by finding the results of the research obtained from doing the observation, distributing the questionnaires, and interviewing the students and the lecturers that can be figured out as follows.

\section{A. The Results of Observation}

In doing the research, the data were obtained by doing the unstructured observation in classroom, delivering questionnaires to students and performing the interview with the students and lecturers. From the unstructured observation in classroom, in the form of 'Sit In' activity, it others, and to work in collaborative ways [11]. In addition, implementation. The data are acquired from unstructured observation in

was found that the teamwork building in learning process has been effectively implemented. The lecturer acted as a facilitator, a mentor, a coach, and an assessor in class. In parallel, the students have shown their high motivation to accomplish all assignments in a diverse team. They expressed the values of truthfulness, goodness, fairness, honesty, and humanity in their teamwork activity that built the work in a team effectively and productively. It can be observed in the learning process that there is no conflict during and after the debate at the question-answer (Q-A) session. The students can coordinate each other and work in harmony. They practiced the tolerance with other different religions, prayed before and after the class, avoided religion fanaticism, and respected to each other. The results from observation in the classroom by doing 'Sit-in' activity as mentioned above, it proved that the teamwork soft skill has been developed effectively in the classroom activity.

\section{B. The Results of Questionnaires}

The following is the list of questionnaires distributed to fifty two students of two classes taken randomly to investigate the implementation of teamwork building and execution in the learning process of CB Religiosity class.

Tabel I. The List of Questionnaires

\begin{tabular}{|c|c|}
\hline $\begin{array}{l}\text { Item } \\
\text { No. }\end{array}$ & Statement \\
\hline$I$ & $\begin{array}{l}\text { The CB Religiosity can support the } \\
\text { development of teamwork soft skill for the } \\
\text { students. }\end{array}$ \\
\hline 2 & $\begin{array}{l}\text { I convince that the lecturer of CB Religiosity } \\
\text { can develop the students soft skill in team } \\
\text { working }\end{array}$ \\
\hline 3 & $\begin{array}{l}\text { The lecturer of CB Religiosity can help to } \\
\text { facilitate the learning process in group } \\
\text { discussion. }\end{array}$ \\
\hline 4 & $\begin{array}{l}\text { The students need to get further understanding } \\
\text { about team working in class. }\end{array}$ \\
\hline 5 & $\begin{array}{l}\text { I feel comfortable to leam CB Religiosity wifh } \\
\text { the students of multi religions backpround. }\end{array}$ \\
\hline 6 & $\begin{array}{l}\text { Before and after the class, the student Inust } \\
\text { pray and care with the cleanliness of } \\
\text { classroom. }\end{array}$ \\
\hline 7 & $\begin{array}{l}\text { I let my classmates with different religions to } \\
\text { state their opinion about their beliefs. }\end{array}$ \\
\hline 8 & $\begin{array}{l}\text { I can work in team with other believers in } \\
\text { class. }\end{array}$ \\
\hline 9 & $\begin{array}{l}\text { Discussion about religions can increase the } \\
\text { hammony of intereli gious relationship. }\end{array}$ \\
\hline 10 & $\begin{array}{l}\text { Debates about religions can increase the } \\
\text { conflicts among different beliefs. }\end{array}$ \\
\hline 11 & $\begin{array}{l}\text { I always remind my classmates to pray } \\
\text { regularly. }\end{array}$ \\
\hline 12 & $\begin{array}{l}\text { Every religion must doctrine to live in good } \\
\text { manner. }\end{array}$ \\
\hline 13 & $\begin{array}{l}\text { Interreligious prayer festival IIust be } \\
\text { maintained. }\end{array}$ \\
\hline 14 & $\begin{array}{l}\text { Greeting the festival day to other belief can } \\
\text { increase the interreligious harmony. }\end{array}$ \\
\hline 15 & I avoid the fanatism of my belief \\
\hline 16 & $\begin{array}{l}\text { I feel very impressed to see IIy classmates } \\
\text { conducting their doctrines faihtfully. }\end{array}$ \\
\hline 17 & $\begin{array}{l}\text { Making friendship with other beliefs is Iny } \\
\text { passion. }\end{array}$ \\
\hline 18 & $\begin{array}{l}\text { Different faith will not disturb me to seek } \\
\text { friends. }\end{array}$ \\
\hline 19 & $\begin{array}{l}\text { Each student Irust tolerate with other } \\
\text { believers. }\end{array}$ \\
\hline 20 & $\begin{array}{l}\text { Executing the group assignment by } \\
\text { teamworking with different beliefs must be } \\
\text { effective to achieve the positive results. }\end{array}$ \\
\hline
\end{tabular}

Before answering the questionnaires, the students were requested to state their own religion in the questionnaires form. The results showed that the fifty two students came

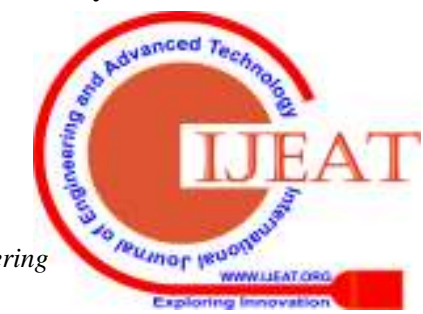


from five different religions (Islam, Christian, Buddhist, Confucian, Catholics) out of six legalized religions (Moslem, Christian, Buddhist, Confucian, Catholic, Hindus) in Indonesia. Based on the theoretical frameworks in chapter 2 , the teamwork is summarized as a group of collaborative persons that work with accountability, honesty, reliability, responsibility in togetherness to achieve the same purposes. Below is the result of the questionnaires that can be seen from the following table as the distribution of respondents in differrent religions.

Table II. The Religions of Respondents

\begin{tabular}{|c|c|c|}
\hline No & Religion & Total Students \\
\hline 1 & Moslem & 20 \\
\hline 2 & Christian & 8 \\
\hline 3 & Catholic & 11 \\
\hline 4 & Hindus & 0 \\
\hline 5 & Buddhist & 12 \\
\hline 6 & Confucian & 1 \\
\hline & Total & 52 \\
\hline
\end{tabular}

The above table shows the distribution of Religions hold by the respondents or the students. It means that the class composition is formed by multi religions background.

The next table is the result of questionnaires responded by the fifty two students.

Table III. The Response of Respondents

\begin{tabular}{|c|c|c|c|c|c|c|c|c|c|c|c|}
\hline $\begin{array}{c}\text { Item } \\
\text { No }\end{array}$ & SS & $\%$ & S & $\%$ & RG & $\%$ & TS & $\%$ & STS & $\%$ & Jml \\
\hline 1 & 21 & 40 & 25 & 48 & 6 & 12 & 0 & 0 & 0 & 0 & 52 \\
\hline 2 & 13 & 25 & 25 & 48 & 8 & 15 & 6 & 12 & 0 & 0 & 52 \\
\hline 3 & 17 & 33 & 24 & 46 & 6 & 12 & 5 & 10 & 0 & 0 & 52 \\
\hline 4 & 19 & 37 & 24 & 46 & 7 & 13 & 2 & 4 & 0 & 0 & 52 \\
\hline 5 & 18 & 35 & 23 & 44 & 7 & 13 & 4 & 8 & 0 & 0 & 52 \\
\hline 6 & 33 & 63 & 16 & 31 & 3 & 0 & 0 & 0 & 0 & 0 & 52 \\
\hline 7 & 33 & 63 & 19 & 37 & 0 & 0 & 0 & 0 & 0 & 0 & 52 \\
\hline 8 & 35 & 67 & 17 & 33 & 0 & 0 & 0 & 0 & 0 & 0 & 52 \\
\hline 9 & 27 & 52 & 20 & 38 & 5 & 10 & 0 & 0 & 0 & 0 & 52 \\
\hline 10 & 0 & 0 & 8 & 15 & 5 & 10 & 20 & 38 & 19 & 37 & 52 \\
\hline 11 & 5 & 10 & 22 & 42 & 20 & 38 & 4 & 8 & 1 & 2 & 52 \\
\hline 12 & 36 & 69 & 16 & 31 & 0 & 0 & 0 & 0 & 0 & 0 & 52 \\
\hline 13 & 29 & 56 & 18 & 35 & 5 & 9 & 0 & 0 & 0 & 0 & 52 \\
\hline 14 & 24 & 46 & 21 & 40 & 6 & 12 & 0 & 0 & 1 & 2 & 52 \\
\hline 15 & 27 & 52 & 22 & 42 & 2 & 4 & 1 & 2 & 0 & 0 & 52 \\
\hline 16 & 29 & 56 & 21 & 40 & 2 & 4 & 0 & 0 & 0 & 0 & 52 \\
\hline 17 & 18 & 35 & 31 & 60 & 3 & 6 & 0 & 0 & 0 & 0 & 52 \\
\hline 18 & 32 & 61 & 16 & 31 & 3 & 6 & 0 & 0 & 1 & 2 & 52 \\
\hline 19 & 42 & 81 & 10 & 19 & 0 & 0 & 0 & 0 & 0 & 0 & 52 \\
\hline 20 & 25 & 48 & 24 & 46 & 3 & 6 & 0 & 0 & 0 & 0 & 52 \\
\hline
\end{tabular}

The questions were delivered in Indonesian language in order to help the students to answer the questionnaires. The followings are the explanation of the result of the research by distributing questionnaires with the initials SS (Strongly
Agree), S (Agree), RG (Doubt), TS (Disagree), STS (Strongly Disagree):

1) $40 \%$ of the students strongly agree, $48 \%$ agree, $12 \%$ doubt, showing that the learning of Character Building (CB) Religiosity really supported the development of the student teamwork soft skill in BINUS University. Most of the students agree that the lecturer delivered the learning process well.

2) $25 \%$ of the students strongly agree, $48 \%$ agree, $15 \%$ doubt and $12 \%$ disagree, showing that the students agree with the lecturer skill in developing the student skill of teamwork as the result of CB Religiosity learning process.

3) $33 \%$ of the students strongly agree, $46 \%$ agree, $11 \%$ doubt and $10 \%$ disagree, showing that most of the students agree with the lecturer as facilitator for learning process by using the group discussion strategy.

4) $37 \%$ of the students strongly agree, $46 \%$ agree, $13 \%$ doubt, and $4 \%$ disagree, showing that the students can understand the benefits of teamwork activity in learning process.

5) $35 \%$ of the students strongly agree, $44 \%$ agree, $13 \%$ doubt, $8 \%$ strongly disagree, showing that most of the students agree with the lecturer giving comfortable in learning CB Religion in class activity.

6) $63 \%$ of the students strongly agree, $31 \%$ agree, $6 \%$ doubt, showing that the students strongly agree to pray before the class begin and to care for the cleanliness of classroom.

7) $63 \%$ of the students strongly agree and $37 \%$ agree, showing that most of the students give opportunity to other believers in the class to express their opinions.

8) $67 \%$ of the students strongly agree and $33 \%$ agree, showing that the students need to work in team even though they have different religion.

9) $52 \%$ of the students strongly agree, $38 \%$ agree, $10 \%$ doubt, showing that discussion about multiculturalism may increase the good relationship among believers.

10) $15 \%$ of the students agree, $10 \%$ doubt, $38 \%$ disagree, $37 \%$ strongly disagree, showing that there was conflict among different religions of the students hold because of different views.

11) $10 \%$ of the students strongly agree, $42 \%$ agree, $38 \%$ doubt, $8 \%$ disagree and $20 \%$ strongly disagree, showing that most students always reminded other believers when it was time to pray and worship.

12) $69 \%$ of the students strongly agree and $31 \%$ agree, showing that they agreed with most of religion teaching about good ethics.

13) $56 \%$ of the students strongly agree, $35 \%$ agree, $9 \%$ doubt, showing that the worship together among believers good to implement.

14) $46 \%$ of the students strongly agree, $40 \%$ agree, $12 \%$ doubt and $2 \%$ strongly disagree, showing that expressing the greeting for other religion festival was a good way to maintain good relationship among believers.

15) $52 \%$ of the students strongly agree, $42 \%$ agree, $4 \%$ doubt and $2 \%$ strongly disagree, showing that most of students avoid fanaticism. 
16) $56 \%$ of the students strongly agree, $40 \%$ agree, $4 \%$ doubt, showing that most of the students were happy to see other believers worship faithfully.

17) $35 \%$ of the students strongly agree, $59 \%$ agree, $6 \%$ doubt, showing that most of the students were happy to make other believers happy.

18) $61 \%$ of the students strongly agree, $31 \%$ agree, $2 \%$ strongly disagree, showing that they did not select the same religion for making friendship.

19) $81 \%$ of the students strongly agree and $19 \%$ agree, showing that most of the students keep tolerance and care for each other believers.

20) $48 \%$ of the students strongly agree, $46 \%$ agree and $6 \%$ doubt, showing that teamwork in doing the assignment among believers were very effective to develop teamwork soft skill.

These data proved that the multi-religious students existed in the class. There were twenty questions in the questionnaire classified into four categories: 1) the role of lecturers, 2) the effectiveness of learning process, 3) the supporting factors, and 4) the impacts of learning process to the students' character and achievements. The following descriptions are the results of the questionnaires. First, 80\% of the students agreed that the lecturers had the capability to integrate their skills in facilitating the learning process to develop the soft skill 'teamwork' to the students. Second, $91 \%$ of the students agreed that they achieved the significant development of their soft skill 'teamwork' through the learning process. Third, $85 \%$ of the students agreed that all assignments given by the lecturers were not result oriented but process experience. The students experienced the teamwork activities and achieved the good final results. Fourth, $95 \%$ of the students agreed that the learning process focusing on teamwork soft skill development gave strong impacts to the students' characters and achievements.

\section{The Results of Interview}

From the results of the unstructured interview with the three lecturers in an informal manner, it showed that the lecturers conducted their roles as facilitators, coaches, mentors, and assessor with full commitments. All lecturers assigned the students to work in a team to do a project, delivered a presentation, did the discussion and sharing. Those activities obliged the students to participate actively by disregarding the diversity in religions and other backgrounds. The lecturers also stated that they became the role model in facilitating the learning process, were the coach for mentoring, and turned out to be the assessor for the achievement of the students in teamwork.

All above processes have given strong impacts to the students' character and achievement. During and after the class, the students show their religiosity, tolerance for diversity, and diffusion in inter-religion. At the end, they can gain the high achievement for the team assignments, Mid Test, Final Test and also the Employability and Entrepreneurship Skill (EES) as one of skill measurements for the students at Bina Nusantara University. In the future, the students as agents of change are expected to apply their teamwork soft skill in business environment for business interaction effectively and efficiently.

\section{REFERENCES}

1. Benawa A, Peter R, Makmun S. The Effectiveness of Full Day School System for Students' Character Building. In IOP Conference Series: Materials Science and Engineering 2018 Jan (Vol. 288, No. 1, p. 012160). IOP Publishing.

2. Bahari H. Toleransi Beragama Mahasiswa (Studi tentang Pengaruh Kepribadian, Keterlibatan Organisasi, Hasil Belajar Pendidikan Agama, dan Lingkungan Pendidikan terhadap Toleransi Mahasiswa Berbeda Agama pada 7 Perguruan Tinggi Umum Negeri), Laporan Penelitian. Jakarta: Badan Litbang dan Diklat Kementrian Agama. 2010.

3. Woodward I, Skrbis Z, Bean C. Attitudes towards globalization and cosmopolitanism: cultural diversity, personal consumption and the national economy. The British journal of sociology. 2008 Jun;59(2):207-26.

4. Raka G, Mulyana Y, Markam SS, Semiawan CR, Hasan SH, Bastaman HD, Nurachman N. Pendidikan karakter di sekolah: Dari gagasan ke tindakan. Jakarta: PT Gramedia. 2011.

5. Ferguson. Career Skills Library: Teamwork Skills. New York: Ferguson Publishing, 2009.

6. Sopiah. Perilaku Organisasi. Yogyakarta: Andi Publishing, 2008.

7. Judge TA, Robbins SP. Perilaku Organisasi Organizational Behavior. Penerjemah Diana Angelica, et al., Jakarta: Salemba Empat. Buku. 2008;1.

8. Allen A. Jean. Strategi membangun tim tangguh. Jakarta: Prestasi Pustaka Publisher, 2004.

9. Ruiz Ulloa BC, Adams SG. Attitude toward teamwork and effective teaming. Team Performance Management An International Journal. 2004 Oct 1;10(7/8):145-51.

10. Fios F, Manurung C, Peter R. Multicultural Education as A Must in Indonesia (A Hermeneutic Analysis to Bina Nusantara University Student's Perceptions Towards ASEAN Community). Advanced Science Letters. 2017 Feb 1;23(2):916-9.

11. Putranto NA, Woods P. Comparison Indonesian and Australian Students' Cultural Intelligence and Attitude towards Teamwork: Case study of Institut Teknologi Bandung and Griffith University. Sains Humanika. 2016 Jan 27;8(1-2).

12. Rachmat, N. Beriman dan Beragama: Membangun Relasi dengan Tuhan dan Sesama. Jakarta: Hegel Pustaka, 2015.

13. Nazir, M. Metode Penelitian. Bogor: Ghalia Indonesia, 2005.

\section{AUTHORS PROFILE}

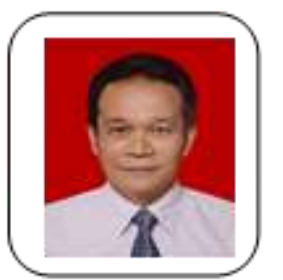

Ramot Peter was graduated his bachelor degree in year 1991 from English Teaching Faculty of Sriwijaya University in Palembang of Indonesia and his master degree in year 2009 from Bethel Theology Seminary in Jakarta of Indonesia. Currently he is pursuing his doctoral degree at Ekumene Theology Seminary in Jakarta of Indonesia. He has been teaching the Character Education (Religiosity, Citizenship, Pancasila as Indonesian Ideology) at Bina Nusantara University in Jakarta of Indonesia since year 2011. During his teaching career, he actively did the yearly research in relation with Character Education (Religiosity, Citizenship, Pancasila as Indonesian Ideology) by getting grants award from Bina Nusantara University in Jakarta of Indonesia. His international publications, among others, include: The Effectiveness of Full Day School System for Students' Character Building (IOP Conference Series, 2018); Multicultural Education as A Must in Indonesia (A Hermeneutic Analysis to Bina Nusantara University

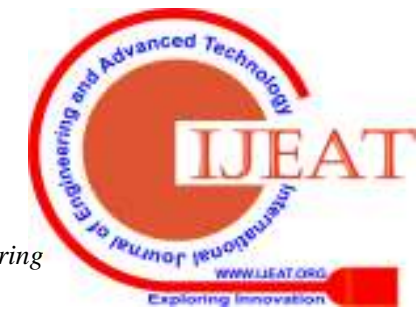


International Conference on Recents Advancements in Engineering and Technology (ICRAET-18) |15th and 16th March 2019|Siddhartha Institute of Technology \& Sciences, Telangana, India.

Student's Perceptions Toward ASEAN Community) (Advanced Science Letters, 2017). Those publications are based on research works granted by Bina Nusantara University in Jakarta of Indonesia. In every semester, he dedicates himself for experiencing the community services as social and spiritual speaker to orphanage boards and schools in relation with Character Education (Religiosity, Citizenship, Pancasila as Indonesian Ideology). Since year 2011 he has joined as member of Universal Peace Federation (UPF) of NGO-UN in Jakarta of Indonesia with major concerning to Interfaith Harmony and Youth Motivating by executing the seminar and workshop in all cities of Indonesia.

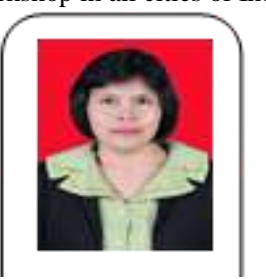

Masda Surti Simatupang is a professional lecturer in the field of English applied linguistics, English education, and English teaching with technology. She was graduated and obtained her Bachelor degree in English Education from Sriwijaya University Palembang in 1991. During her bachelor study, she gained scholarship from the Higher Education Ministry of Indonesia for three years. She obtained her master degree in English Applied Linguistics from Atmajaya University in Jakarta in 2000. She was awarded full scholarship from Christian University of Indonesia throughout the master study for three years. Her Doctoral degree in Language Education from Jakarta State University was in 2016. She was also awarded scholarship from the Higher Education Ministry of Indonesia for four years during her doctoral study. Furthermore, she was granted Overseas Sandwich-like scholarship from the Higher Education Ministry of Indonesia to go to Illinois University of the United States for four months from September to December 2011 to do research, to do school visiting, to broaden her insight, and to have abroad educational experience. Her publications, among others, include Assessing speaking by $\mathrm{f} 2 \mathrm{f}$ or using a developed application: Area there any differences? (2018); Video Games and the Improvement of English Learning: University Students Perspective (2017); Instructional Model of English Speed Reading (Research and Development at Christian University of Indonesia) (2016). Those publications are based on research works which more or less similar titles. She is a member of Teachers of English as a Foreign Language (TEFL) Asia and Indonesia Linguistics Community. 